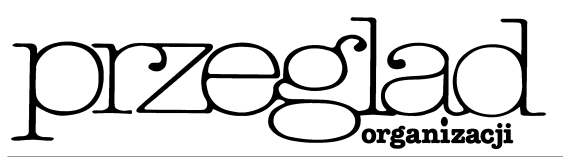

\title{
Wybrane zastosowania rachunku aktualizacji
}

https://doi.org/10.33141/po.2005.11.09

\section{Juliusz Wójcik}

\section{Wstęp}

W artykule przedstawiono dwa przykłady zastosowania rachunku aktualizacji. Są to kredyt składany i oscylator. Cechą wspólną tych przykładów jest wpływ wielkości stopy procentowej na efektywność działań. O ile kredyt składany służy do realizacji projektu inwestycyjnego, to oscylator jest niewątpliwie działaniem szkodliwym - umożliwia wyprowadzenie z systemu bankowego dużego kapitału.

W projektowaniu inżynierskim rachunek aktualizacji stosowany jest do oceny projektu pod względem jego efektywności ekonomicznej. Dla ustalonej stopy procentowej wyznacza się czas zwrotu poniesionych nakładów inwestycyjnych, których źródłem jest kredyt bankowy. Czas zwrotu nakładów powinien być jak najkrótszy, po jego upływie wzrasta zdolność do akumulacji środków własnych przedsiębiorstwa, które z kolei mogą być inwestowane w dalszy jego rozwój. Wysoki poziom stopy procentowej może stanowić zbyt wielkie obciążenie finansowe dla przedsiębiorcy, zwłaszcza gdy charakter inwestycji wymusza długotrwały okres budowy projektu. Rozłożone w czasie finansowanie za pomocą tzw. kredytu składanego generuje zadłużenie, którego wielkość rośnie szybciej po przekroczeniu pewnego progu stopy procentowej. W pracy oszacowano jego wartość.

Nie tak dawno jeszcze obserwowano wpływ zmian stóp procentowych na ożywienie gospodarcze w USA. Zatem wielkość stopy procentowej może odnieść zamierzony skutek gospodarczy. Jej wartość ustalana jest w określonych uwarunkowaniach gospodarczych, jednak problematyka ta wykracza poza temat tej pracy. Zwrócono natomiast uwagę na fakt, że zbyt wysokie oprocentowanie może doprowadzić do działań szkodliwych, których skala jest trudna do oszacowania. Takim działaniem jest oscylator. W artykule przedstawiono schemat oscylatora i wyprowadzono formułę na wartość osiaganego zysku w wyniku jego stosowania.

\section{Kredyt składany}

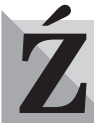

ródłem kłopotów w procesie inwestycyjnym mogą być niekorzystne warunki kredytowania lub nieprawidłowo wykonany projekt, który w fazie eksploatacji nie generuje spodziewanych pierwotnie dochodów.

Ocenę projektu dokonuje się na podstawie funkcji NPV (Net Present Value) [1]

$$
N P V=\sum_{i=1}^{n} \frac{N C F_{i}}{(1+r)^{i}}-C
$$

Przegląd Organizacji, Nr 11 (790), 2005, ss. 33-36 www.przegladorganizacji.pl Towarzystwo Naukowe Organizacji i Kierownictwa (TNOiK)
Wyrażenie pod znakiem sumy to zdyskontowane roczne wpływy netto $\mathrm{NCF}_{i}$ (Net Cash Flow) z $i$-tego roku eksploatacji projektu, $r$ - stopa dyskontowa. Dla $N P V=0$ wyznacza się czas zwrotu poniesionych nakładów inwestycyjnych $C$. Długi czas spłaty zaciągniętego kredytu stwarza trudną sytuację dla inwestora wpływy mogą okazać się mniejsze niż uprzednio szacowano, np. w skutek spadku atrakcyjności produkowanych przez długi okres tych samych towarów. Typowy przebieg funkcji $N P V$, dla przykładowych danych, przedstawiono na rys. 1 .

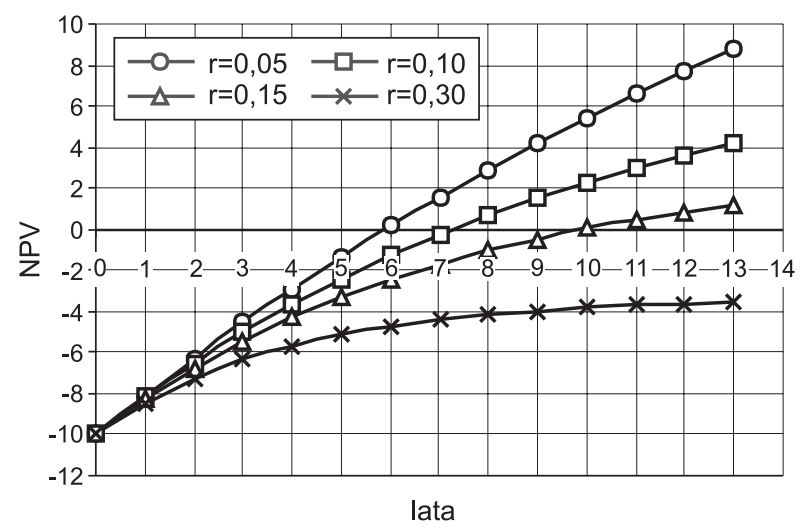

Rys. 1. Wpływ wielkości stopy procentowej na przebieg funkcji NPV dla $\mathrm{C}=10, \mathrm{NCF}=$ const. $=2$

Zależność (1a) jest dobrze znana, gdy $C$ oznacza jednorazowe nakłady inwestycyjne, a efekty spodziewane sa już po upływie roku (stąd sumowanie od $i=1$ ). Sytuacja taka ma miejsce w przypadku małych projektów lub projektów cząstkowych np. dotyczących modernizacji parku maszynowego, zakupu sprzętu informatycznego czy wprowadzania systemu zarządzania jakością. W przypadku dużych projektów (np. budowa przedsiębiorstwa, modernizacja infrastruktury gminy, rozwój danego sektora gospodarki kraju) uruchamiana jest linia kredytowa i inwestor pobiera coroczne transze kredytowe. Spłata takiego kredytu składanego rozpoczyna się po zakończeniu budowy, a konkretnie po pierwszym roku eksploatacji projektu.

Cały projekt składa się więc z fazy inwestycyjnej i eksploatacyjnej, przy czym aktualizację środków przeprowadza się dla chwili kończącej okres inwestycji. Na rys. 2 przedstawiono przebieg krzywej NPV, obrazującej wartości zaktualizowane środków w fazie budowy i eksploatacji projektu. Dla uproszczenia przyjęto, że jego finansowanie polega na pobieraniu równych transz kredytowych $k$ przez cały okres budowy. 


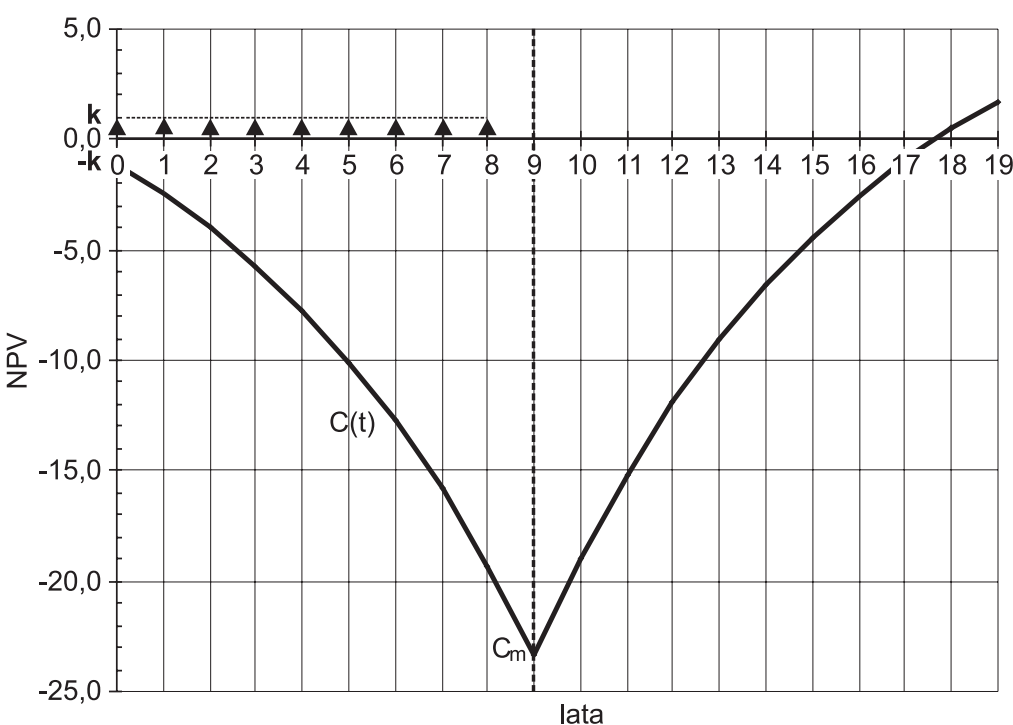

Rys. 2. Przebieg funkcji NPV dla projektu o długim procesie inwestycyjnym $\left(k=1 ; r=0,15 ; N F_{i}=5 ; i=1, \ldots, n\right)$

Na rys. 2 pokazano, że okres budowy wynosi 9 lat i w tym czasie pobrano 9 równych transz kredytowych. Spłata pierwszej raty od całego kredytu następuje w rok po rozpoczęciu fazy eksploatacji projektu, gdy zaczyna on przynosić zyski. Istotna jest zatem szybkość zadłużania się w fazie budowy, ponieważ od całkowitego - wynikowego zadłużenia $C_{m}$ zależy wielkość raty kapitałowej.

Dla kredytu składanego wyrażenie na wartość zaktualizowaną netto $N P V$ przyjmie postać

$$
N P V=\sum_{i=1}^{n} \frac{N C F_{i}}{(1+r)^{i}}-C(t)
$$

Funkcję zadłużenia $C(t)$ wyznacza się rachunkiem oprocentowania składanego:

$$
C(t)=\sum_{t=0}^{m-1} k(1+r)^{m-t}
$$

gdzie $m$ jest czasem budowy projektu wyrażonym w latach, $t$ - czasem, w którym pobierana jest transza kredytowa. Po rozwinięciu prawej strony równania (2) i obliczeniu sumy ciągu geometrycznego o parametrach $a_{1}=(1+r)^{m}$ i postępie $q=(1+r)^{-1}$, można wyznaczyć całkowite zadłużenie $C_{m}$ :

$$
C_{m}=k \times \frac{1+r}{r}\left[(1+r)^{m}-1\right]
$$

Wartość $C_{m}$ oznacza również koszt budowy projektu. Jego ewentualna sprzedaż odbywa się po cenie wyższej od kosztu budowy, zatem szybkość zadłużania wpływa na atrakcyjność oferty. Przykładem realizacji projektu „pod klucz” jest budowa autostrad. Czynnik czasowy jest zależny od kredytobiorcy - inwestora, w jego interesie jest jak najszybsza budowa projektu. Zatem konieczna jest dbałość o jego jakość, szczególnie o optymalizację harmonogramu prac. Wysokość oprocentowania kredytu - środków inwestycyjnych zależy od banku. Na rys. 3 przedstawiono wpływ stopy procentowej na wielkość zadłużenia - koszt budowy projektu.

Funkcja $C_{m}(r)$ jest ciagła i różniczkowalna dla $r>0$. Dla $r \rightarrow 0$ zachodzi $\lim _{r \rightarrow 0} C_{m}(r)=k m$.

${ }^{\prime}$ Charakter krzywej $C_{m}(r)$ wskazuje (rys. 3), że ze wzrostem $r$ przyrost zadłużenia jest widoczny, jednak rośnie ono znacznie szybciej po przekroczeniu pewnych wartości $r$. Aby oszacować „bezpieczne” wartości $r$, należy wykorzystać wspomnianą wcześniej własność funkcji $C_{m}(r)$ i obliczyć jej pochodną względem $r$, która wynosi

$\frac{d C_{m}}{d r}=\frac{k}{r^{2}} \times\left[(1+r)^{m}(r m-1)+1\right]$

Przyrównując pochodną do zera, dla $r>0$ otrzymamy

$$
(1+r)^{m}(r m-1)=-1
$$

Ponieważ $(1+r)^{m}>0$, zatem, aby lewa strona równania (5) była ujemna, musi być spełniony warunek

$$
r m-1<0
$$

Z nierówności (6) wynika oszacowanie „bezpiecznej" wartości stopy procentowej

$$
r<\frac{1}{m}
$$

Wykorzystując zależność (7a) dla przykładu z rys. 3 można oszacować możliwą do zaakceptowania stopę procentową, która w tym przypadku powinna być mniejsza od 1/9 (ok. 11\%).

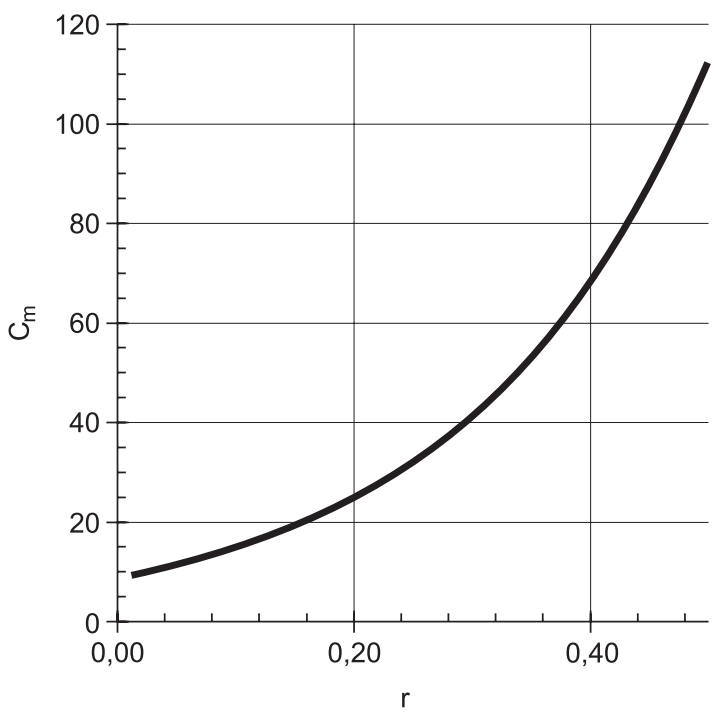

Rys. 3. Wpływ stopy procentowej na koszty inwestycji, dla $k=1, m=9$ 


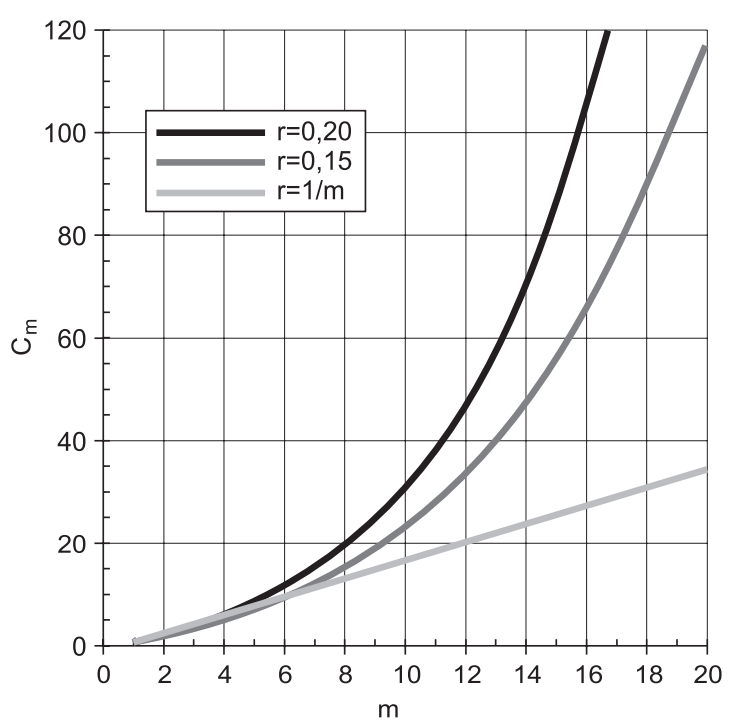

Rys. 4. Wpływ czasu budowy projektu na zadłużenie dla różnych wartości oprocentowania kredytu $(k=1)$

Wielkość stopy procentowej ma duże znaczenie w przypadku inwestycji długoterminowych. Odległa perspektywa spłaty zadłużenia może jednak spowodować np. zaniedbania w negocjacji warunków kredytowych czy obniżenie dyscypliny realizacji fazy inwestycyjnej. W efekcie, nawet starannie przygotowany projekt może zakończyć się fiaskiem. Na rys. 4 pokazano wpływ czasu budowy projektu na zadłużenie dla przykładowych wartości oprocentowania kredytu. Zadłużenie dla warunku (7a) jest mniejsze niż wartości krzywej $C_{m}(m)_{r=1 / m}$.

Gdy inwestor nie ma wpływu na oprocentowanie kredytu, wówczas pozostaje mu skorygowanie projektu celem skrócenia czasu jego budowy tak, aby spełnione było

$$
m<\frac{1}{r}
$$

\section{Oscylator}

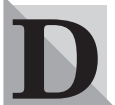

ziałania wykorzystujące różnice wielkości stóp procentowych, polegające na zaciąganiu kredytu w jednym banku i deponowaniu uzyskanego kapitału w innym banku, noszą nazwę oscylatora. Zaciąganie kredytu następuje w banku o stopie procentowej $r$. Deponowanie środków odbywa się w banku o stopie procentowej $r_{0}$. Warunkiem wystapienia oscylatora jest, aby $r_{0}>r$.

Spełnienie tego warunku mogłoby wydawać się nierealne. Jednak w Polsce na początku lat 90. ub. wieku stopy procentowe od lokat były większe od oprocentowania kredytu w bankach zachodnich.

Ważna jest forma zabezpieczenia bankowego na udzielany kredyt. W oscylatorze formą zabezpieczenia była gwarancja udzielana przez bank, w którym deponowano walory pieniężne. Na początku okresu rozliczeniowego bank udzielał gwarancji (poręczał), że po upływie danego okresu (np. 1 roku) klient będzie dysponował określoną kwotą. Na podstawie poręczenia bankowego zaciagany był kredyt w innym banku.
Niech $k$ oznacza pewną kwotę bazową, na która istnieje realne zabezpieczenie, $\mathrm{np}$. w postaci środków trwałych. Zaciągnięcie kredytu na wartość $k /(1+r)$ spowoduje, że po roku do banku należy zwrócić kwotę $k$, co wynika z rachunku aktualizacji. Bank udzieli kredytu, ponieważ na $k$ jest zabezpieczenie majątkowe. Jeśli następnie w innym banku zostanie zdeponowany kredyt o wartości $k /(1+r)$, to po roku wartość lokaty wzrośnie do $[k /(1+r)]\left(1+r_{0}\right)$. Zysk z przeprowadzonej operacji (dla $r<r_{0}$ ) wyniesie:

$$
Z_{1}=B_{1}^{w}-B_{1}^{z}=\frac{k}{(1+r)} \times\left(1+r_{0}\right)-k=k \times\left(\frac{r_{0}-r}{1+r}\right)
$$

gdzie $B_{1}^{w}$ oznacza kwotę gwarantowaną przez bank, w którym dokonywana jest lokata, $B_{1}^{z}$ - oznacza kwotę, jaką po roku należy zwrócić do banku, w którym zaciagnięto kredyt. Górne indeksy $w$ i $z$ umiejscawiają bank odpowiednio $\mathrm{w}$ wewnętrznym i zewnętrznym systemie bankowym. Dolne indeksy cyfrowe identyfikują kolejny krok oscylatora. Równanie (8) opisuje pierwszy jego krok. W następnych krokach czynności są powtarzane, jednak wielkości kredytów i lokat ulegaja zmianom. Schemat oscylatora przedstawiono na rys. 5. Efektem pierwszego kroku jest wzrost gwarantowanej kwoty bazowej z $k$ do $k \times \frac{1+r_{0}}{1+r}=B_{1}^{w}$.

$\mathrm{W}$ drugim kroku oscylatora, w banku zagranicznym (zewnętrznym) jest zaciągany kredyt na kwote $B_{1}^{w} /(1+r)$, który następnie jest deponowany w kolejnym - drugim banku krajowym (wewnętrznym). Zadłużenie od zaciąnniętego kredytu oraz spodziewana kwota od depozytu w drugim kroku oscylatora wyniosą odpowiednio:

$$
\begin{aligned}
& B_{2}^{z}=\frac{k}{(1+r)} \times\left(1+r_{0}\right) \\
& B_{2}^{w}=\frac{k}{(1+r)^{2}} \times\left(1+r_{0}\right)^{2}
\end{aligned}
$$

Efektem drugiego kroku oscylatora jest kolejny wzrost gwarantowanej kwoty bazowej z $k \times \frac{1+r_{0}}{1+r}$ do $k \times\left(\frac{1+r_{0}}{1+r}\right)^{2}=B_{2}^{w}$.

Liczba kroków $n$ oscylatora jest dowolna, jednak zaciagganie kredytu i deponowanie środków musi odbywać się możliwie w tym samym czasie.

Zysk generowany po upływie roku, z pierwszego kroku oscylatora opisuje równanie (8), z kolejnych kroków zyski wynoszą:

$$
\begin{aligned}
Z_{2}=B_{2}^{w}-B_{2}^{z} & =k \times\left(\frac{1+r_{0}}{1+r}\right)^{2}-k \times\left(\frac{1+r_{0}}{1+r}\right)= \\
& =k \times \frac{1+r_{0}}{1+r} \times\left(\frac{r_{0}-r}{1+r}\right) \\
Z_{3}=B_{3}^{w}-B_{3}^{z} & =k \times\left(\frac{1+r_{0}}{1+r}\right)^{3}-k \times\left(\frac{1+r_{0}}{1+r}\right)^{2}= \\
& =k \times\left(\frac{1+r_{0}}{1+r}\right)^{2}\left(\frac{r_{0}-r}{1+r}\right) \\
\vdots \quad & \\
Z_{n}=B_{n}^{w}-B_{n}^{z} & =k \times\left(\frac{1+r_{0}}{1+r}\right)^{n}-k \times\left(\frac{1+r_{0}}{1+r}\right)^{n-1}= \\
& =k \times\left(\frac{1+r_{0}}{1+r}\right)^{n-1}\left(\frac{r_{0}-r}{1+r}\right)
\end{aligned}
$$




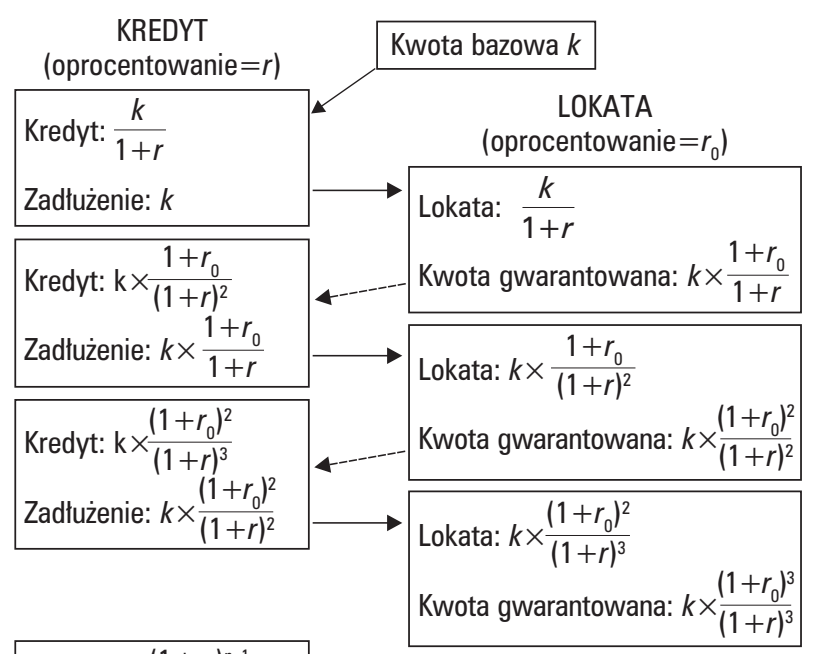

\begin{tabular}{|l|l|} 
Kredyt: $\mathrm{k} \times \frac{\left(1+r_{0}\right)^{n-1}}{(1+r)^{n}}$ \\
Zadłużenie: $k \times \frac{\left(1+r_{0}\right)^{n-1}}{(1+r)^{n-1}}$
\end{tabular}$\longrightarrow \begin{aligned} & \text { Lokata: } k \times \frac{\left(1+r_{0}\right)^{n-1}}{(1+r)^{n}} \\
& \text { Kwota gwarantowana: } k \times \frac{\left(1+r_{0}\right)^{n}}{(1+r)^{n}}\end{aligned}$

$\longleftarrow$ zaciąganie kredytu na podstawie gwarancji bankowych 4---- lokata kapitału

Rys. 5. Schemat oscylatora $\left(r_{0}>r\right)$ (opis w tekście)

Obliczając sumę zysków w każdym kroku oscylatora uzyskuje się wyrażenie:

$$
\sum_{i=1}^{n} Z_{i}=k \times\left(\frac{r_{0}-r}{1+r}\right)\left[1+\frac{1+r_{0}}{1+r}+\left(\frac{1+r_{0}}{1+r}\right)^{2}+\Lambda+\left(\frac{1+r_{0}}{1+r}\right)^{n-1}\right]
$$

które w nawiasach kwadratowych zawiera sumę ciągu geometrycznego o postępie $\left(1+r_{0}\right) /(1+r)$. Po obliczeniu sumy ciagu i przekształceniach otrzymuje się formułę na wyznaczanie zysku oscylatora w wyniku $n$ oscylacji

$$
Z_{\text {osc }}=\sum_{i=1}^{n} Z_{i}=k\left[\left(\frac{1+r_{0}}{1+r}\right)^{n}-1\right]
$$

Nasuwa się pytanie, jaką realną wartość może przyjąć wielkość $Z_{\text {osc }}$. Na początku lat 90 . ub. wieku oprocentowanie wkładów bankowych w Polsce wynosiło średnio ok. 70\%. Jeśli przyjać, że w tym samym czasie oprocentowanie kredytów komercyjnych w Europie Zachodniej wynosiło ok. $20 \%$, to dysponując kwota wyjściową (bazową) np. $k=1 \mathrm{mln}$ USD, w ciągu roku można było „zarobić” 31,559 mln USD netto (dla $n=10$ ). Zastosowanie w tamtym czasie oscylatora kojarzono w środkach przekazu z firmą Art-B, jednak faktyczna skala zjawiska pozostanie chyba nie wyjaśniona.

\section{Dyskusja i wnioski}

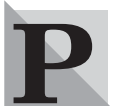

rzyjmuje się, że wysoki poziom stóp procentowych sprzyja oszczędzaniu lub precyzyjniej lokowaniu posiadanego kapitału w banku. Maleje wówczas siła nabywcza, zmniejsza się popyt na towary i wyhamowuje się tendencję wzrostu ich cen. Jest to typowy mechanizm walki z inflacją popytową. Odmienny charakter od popytowej ma inflacja kosztowa, a walka z nią jest bardziej złożona. Wysoki poziom stóp procentowych może skutecznie wyhamować proces inwestycyjny niezbędny do ciągłego i perspektywicznego funkcjonowania podmiotu gospodarczego. Długi czas spłat rat kapitałowych od nagromadzonego zadłużenia w procesie inwestycyjnym faktycznie przybiera formę dofinansowywania sektora bankowego. Funkcja stymulowania rozwoju gospodarczego przez ten sektor staje się problematyczna.

$\mathrm{Na}$ początku lat 90 . ub. wieku ok. $70 \%$ środków inwestycyjnych pochodziło z kredytów zaciąganych w bankach zagranicznych [2], gdzie oprocentowanie kredytu było niższe niż w bankach polskich. Powstało wielomiliardowe zadłużenie zagraniczne polskich przedsiębiorstw. Do Polski napływały inwestycje zachodnie, niestety część z nich o charakterze spekulacyjnym. Do działań o takim charakterze zalicza się również oscylator. Inwestorzy zagraniczni, finansowani tanimi kredytami przez rodzime banki, byli groźna konkurencją dla inwestorów polskich, których aktywność gwałtownie spadła.

Wyznaczone oszacowanie progu bezpiecznego oprocentowania kredytu składanego ma zastosowanie dla inwestycji długoterminowych. Ich realizacja obarczona jest zwiększonym ryzykiem, na który, oprócz warunków kredytowych, może mieć wpływ rotacja kadr. Ma to miejsce np. przy realizacji zadań inwestycyjnych gminy. Zadłużenie podmiotów gospodarczych kredytem długoterminowym (powyżej 5 lat) wynosiło 5,2 mld zł w 1991 roku i wzrosło do 20,5 mld zł w 1996 roku [2]. Motywy zadłużania były różne. Oprócz charakteru typowo inwestycyjnego zadłużanie się przedsiębiorstw miało również charakter egzystencjonalny - wysoko oprocentowane kredyty służyły do zapewnienia ciąłości produkcji. Szybkość generowanego zadłużenia była większa niż kumulacja zysków. Środki przekazu często informowały o skali zadłużenia przedsiębiorstw.

Względnie wysoki poziom stóp procentowych oprócz negatywnych skutków może spełniać rolę bariery zapobiegającej przeinwestowaniu pewnych gałęzi gospodarki. Finansowanie inwestycji w słabo rozwiniętych gałęziach może odbywać się nisko oprocentowanym kredytem preferencyjnym. Jest to rodzaj działalności inwestycyjnej państwa. Zwrot poniesionych nakładów ma różne źródła, np. zwiększone wpływy budżetowe z podatku obrotowego, dochodowego, mniejsze wydatki socjalne (redukcja bezrobocia). Zarysowuje się więc ważna rola państwa w programowaniu i pośrednio w sterowaniu rozwojem gospodarczym. Głównym narzędziem w realizacji tych zadań jest sektor bankowy.

dr inż. Juliusz Wójcik Katedra Zarządzania Jakością Procesów i Produktów Wydział Organizacji i Zarządzania Politechniki Śląskiej

\section{BIBLIOGRAFIA}

[1] JANASZ W., Podstawy ekonomiki przemystu, Wydawnictwo Naukowe PWN, Warszawa 1997.

[2] Rocznik Statystyczny 1997, Główny Urząd Statystyczny, Warszawa. 